\title{
Reflexive, Reflexivity, and the Concept of Reflexive Design
}

Margitta Buchert

Editorial Summary: In her contribution "Reflexive, Reflexivity, and the Concept of Reflexive Design« Margitta Buchert frames the notion of reflexive design and research, pitting the various underlying concepts against one another and forming the framework for reflexive design research. As such, she emphasizes the punctuated distinction of reflection as an integrated component of research and of design and reflexion as alignment and attitude. In this sense she highlights the reciprocal interdependence of theory and practice as well as of the thinking and the making. Buchert introduces reflexive research in an attempt to investigate processes of architectural creation and design as well as their proceedings. »Reflexive Design « forms an open method to allow practices and processes of design and research to intertwine. [Katharina Voigt]

Keywords: Design Research; Reflexive Attitude; Sur-Réflexion; Knowledge Generation; Openness.

\section{Starting Points}

Reflexive approaches as research perspectives in architecture reveal their nuances when, initially, the reflexive is considered along with the reflection. It is unlikely that anyone would consider architecture to be a "pure « practice without reflection. Although (as well as due to) being the first known reference to reflective dimensions in architecture, the authority of Vitruvius' Ten Books on Architecture seems unquestioned. He postulated architecture as a science (scientia), with the components of production and reflection, fabrica and ratiocinatio (Oechslin 2009: 26-28). Vitruvius conceived "fabrica« and »ratiocinatio« as knowledge forms of the architect. »Ratiocinatio« is linked to intellectual work, theoretical attentiveness and conception, and it is seen as a foundation for the specific architectural actions and as possibility to explain, show, and develop in relation to production.

Yet, is reflection the essential element that turns search into research, as the British architect and philosopher Ranulph Glanville put forward, who 
with Leon van Schaik etsablished an innovative and international renown Practice andf Research PhD at the RMIT in Melbourne, Australia in the 1990s? (Glanville 2010: 93) Or, do we have to distinguish issues and intensities, perhaps in combination with methodological concerns and/or values, qualities and meaning? (Friedman 2003).

Glanville addressed »design research «, which can be described as being guided by the intertwining of theory and practice in different variations with the purpose of generating knowledge. When examining the workflow of both the design and the research processes, they appear iterative when dealing with complex tasks and targets. Diverse moments and phases of reflection in design and research alike can be observed, which may trigger the process, yet additionally require intensity and extension to present it as a recognizable knowledge form (Cross 1999: 5).

An opportunity to step aside from specific expectations and requirements of given definitions of science - thus providing a base for specificities of architectural research - has been proposed with the concept of »Reflexive Design« (Buchert 2014). In reference, for example, to the theoretical concepts of the French anthropologist Pierre Bourdieu, the reflexive with " $\mathrm{X}$ " and reflexivity as a practice, which owes its specific seductiveness to the notion of radicality, can trigger ways of research leading to a broad variety of creating knowledge (Bourdieu/Wacquant 2001: 174-184).

By going beyond the widespread tripartite of »research for, into and through design", as suggested in the 1990s by the dean of London's College of Arts, Christopher Frayling, and opening up diverse mixing of research-based design, design-oriented research, as well as of self-inquiry and »common ground «, this concept is characterized by a high degree of openness and by increasing individual and collective abilities to handle complexity (Frayling 1993: 5).

»Reflexive Design« highlights a Western and international tradition that views the specific strength and potential of architecture in the capacity to combine art and science, theory and practice, thoughts and feelings, analysis and imagination in exceptional synthesizing ways. This notion should also characterize methodological implications of research. In the realm of the reflexive and reflexivity, this basis can obtain a certain systematicity, an approximation to objectivity, and the potential to generate discourse.

Simultaneously, the artistic creative forces are kept alive by sur-réflexion, as conceived by the philosopher Merleau-Ponty (Merleau-Ponty 2012: 75-76). Thus, the diverse interplays create impulses for continuous active 
renewal of the discipline with innovative ideas and high-quality concepts and projects. This can ultimately generate changes in the built environment through the spaces and places shaped by architecture. The reflexive emerges as an important source of perception and understanding, as a particular type of interplay between conception and production, as well as of insight and cognitive content.

\section{Reflection, Reflexivity, Sur-Réflexion}

The Reflective Practitioner. In the 1980s, the American scientist and urbanist Donald Schön presented the theoretical idea of the »Reflective practitioner . He explored forms of knowledge in practice that were not only based on technical rationality or on logical transparency. Rather, his concept of the reflective was a knowledge-based and at the same time improvisatory approach to complex situations (Schön 2003: 39-69). In reference to the Hungarian-British polymath Michael Polanyi, Schön highlighted that the iterative design process also encompasses tacit knowing, which can only be partially described (Buchert 2011: 80-81). It is influenced by continuously changing degrees of awareness, is often perceived as an intuitive or serendipitous action for those involved, and it focuses on problems and design results.

Furthermore, Schön indicated that there usually exists a base concept of the designer or collective (Schön 1987: 31-35). Such a base concept can be conceived as a direction and attitude that accompanies the various project designs (Lawson 2004: 95-98). It forms a relative constant and interacts with the prevailing situational circumstances in each case, which evolves from the knowledge base within the discipline, as well as from biographical, social and cultural contexts, and which can be enhanced and qualified by research phases (Buchert 2014: 33). As expert research shows, such a background determines professional competence to a significant degree (Lawson 2006: 299-301).

Reflexivity. This context also plays a central role in the concepts developed by the French anthropologist Pierre Bourdieu, who discussed it using the term "habitus« and a primary interest in relationships (Bourdieu 2006: 88). Furthermore, in his ambition to uncover how human action could be understood, Bourdieu qualified reflexivity as a modality of asking questions on 
dispositions, frameworks, and patterns of thinking and action. Moreover, reflexivity is also seen as a penetrating critique of established forms of science from a collective of researchers supporting and strenghtening each other and developing instruments that comply with the kind of knowledges they seek. This concept disregards disciplinary boundaries, crossing theory and practice, ideas and materiality as well as subjective and objective ways of knowing (Bourdieu/Wacquant 1992: 3). Freed from a set of pre-determined conditions, autonomy and invention as well as general insights may be triggered.

There exists a broad field of discourse on reflexivity, which addresses relations between knowledge and the ways of creation through careful interpretation, and by using multiple lenses for stimulating critical awareness. It reveals creativity in the theory and practice of research and the understanding of practices of worldmaking (May/Perry 2017). Moreover, this field encompasses interpretations of contemporary conditions of risks, being postulated as »Reflexive modernization« by Ulrich Beck, Anthony Giddens, and Scott Lash (Beck/Giddens/Lash 1996). In connection with reflexivity, these views not only advocate the role of questioning and reforming the objectives and ideals of modernity, but also the imaginative powerful trigger that reflexivity can be.

Thus, the reflexive and reflexivity act as generators in both epistemological and empirical pursuits. The generation of knowledge in interaction with design practice or even as part of the design process is a specific variation of this alignment. They are in many ways an indication of the reciprocal nature of the perception of, and references to, the world and the self. They can also reveal the foundations, premises, and potentials of design and research practices in architecture, as well as landscape and urban design with projective ambitions.

Sur-Réflexion. A further relevant idea of the reflexive can be found in the work of the philosopher Maurice Merleau-Ponty, who described the factual existence of a human being - perceived on a sensual-physical level - as fundamental for raising awareness. (Merleau-Ponty 1994: 153-159; MerleauPonty 2012). The unfolding experience is based on the embodied presence in a field of relations, which serves as an instrument to be anchored in the world, to configure with it and to make it accessible over time through the dynamic emergence of understanding. Hereby, Merleau-Ponty opted for a plurality of being and recognized the sense of identity and meaningful 
qualities of an active and contextually embedded perception and its continual reset and revitalizing character (Merleau-Ponty 1994: 273-274; MerleauPonty 2012:102, 186). Current research in neuroscience and cognitive science has produced insights that underline such models of the confluence of body and mind (Buchert 2021: 43-44).

Furthermore, Merleau-Ponty's objective was not only to reveal grounds for experiencing, but also to highlight the capacity of reaching beyond existing structures in order to generate others (Merleau-Ponty 1963: 47, 175; Merleau-Ponty 1994: 137-138, 154). Because Merleau-Ponty embraces the ability to surmount the immediate environment and to settle between real and possible worlds, his studies are useful in the 21st century in terms of fluid definitions of the individual and of balancing orientation and disorientation, and at the same time of differentiation (Buchert 2006: 57). In the end, he invited the understanding of vagueness as a positive phenomenon and linked it to artistic ways of producing alterity - to extend, challenge or change perceptions of realities; a competence, which he denoted »sur-réflexion« (Huber 2013: 142-152).

\section{Reflexive Design}

Concept. The concept of »Reflexive Design« draws insights from all of these ideas and discourses on the reflexive and reflexivity. It concerns questions of design research as a practice and its specificity in relation to other practices of world creation. As a mediating concept and by combining reflexivity and design, the aim is to create a more open setting compared to methodically restricted ways of researching. Practices and processes of research and design can interlink in multiple ways, and knowledge forms can appear in different interplays. The concept of »Reflexive Design « was established at the Faculty of Architecture and Landscape Sciences at the Leibniz Universität Hannover as a research topic and is a part of the overarching research focus "Future Habitats«. It is not a method in the first place, but an attitude, an alignment, a modality.

Conceived to reveal and understand individual, collective and overarching features and impacts of the relations between perception, thinking and action, "Reflexive Design« opens up possibilities for exploring the superordinate routes of a wide variety of research questions and procedures. It thereby provides a platform for what they create, for innovative ways of reflection and action corresponding to the complexity of the 21st century, 
and for connecting rational and intuitive attentiveness. It is meant to trigger collective ways of exploring variations of what design research might uncover, working back and forth in a dynamic relationship. Finally, this concept was developed to broaden the knowledge base on best-practice design research projects and to foster the exchange of academia and diverse practices of the disciplines connected to design living environments. Moreover, especially forward-looking conceptions of locally and globally effective, viable contributions to tasks and developments in the design of future habitats should be explored. In sum, this research field encompasses projective activities that focus on the world as it could be.

Setting. Annual international symposia on design and research in architecture and landscape (DARA) and selected publications on the topic constitute the research setting. The essential identity of this framework resides in the inquiring and inventive creation of knowledge. Since 2011, changing subjects and questions have brought office practitioners, professional theorists, $\mathrm{PhDs}$ and postdocs as well as experts from diverse disciplines together, with the objective of developing qualities of design and research, which could be described as fitting for architecture, urban design and landscape architecture in specific ways and features. The practice of reflexivity and the diverse entanglements of design and research thereby unfold as a collective undertaking.

To reveal understanding and a set of tools of and for design research, which can be used from all interested in the »Reflexive Design« field, would be a strong factor for the autonomy of architectural design sciences and act as a starting point for uncovering a particular type of insight and cognitive content without being forced into the aims of a strict methodology. By glancing at Merriam-Webster's definitions for "method «, the descriptions of the enumerated include: a systematic plan, a way, a process, a body of skills, an orderly arrangement, a habitual practice or orderliness and regularity, all of which can be interpreted as elements of systematicity. (HoyningenHuene 2013: 25-30; Merriam-Webster 2019). Reflexivity evokes a process of on-going ordering and can be supported by conscious comparison, including a mixture of well-known methodological tasks, approaches and medias.

Sequence. Each of the tentative subtopic was an experiment in the field of »Reflexive Design« and therefore a research pragmatic instrument, which could simultaneously help outline a theory of practice. One of the objectives 
entails understanding the manifold realms of practice and their development potentials for revealing resources of knowledge. For office practitioners as well as for theoreticians, it additionally opens up the possibility of understanding one's own position in the process of cognitive production. As such, each symposium was explorative and extremely iterative between research-based, design-based, and various combinations of these approaches. Each topic created the possibility for evaluation and further consideration in the awareness of absences and exclusions. At the same time, it became apparent that there are many ways to apply variations of this approach.

The first book, titled »Reflexive Design. Design and Research in Architecture«, presents the concept using different lenses, thereby revealing and discussing its foundations and theories as well as reference fields and the range of the concept as an approach, alignment and attitude. In this regard, the terminology has been contoured as a topological field based on a combination of disciplines and discursive and designerly realms that work together to better understand the concept as a mediating in-between realm (Buchert 2014).

The second publication on the subtopic "Practices « opens up a spectrum and varieties of research possibilities specific to architectural, urban, and landscape design in relation to well-known research foci and the current discourse on them (Buchert 2016). One of these approaches is to be found within the heuristic manner of searching and finding in relation to realworld contexts to reveal new knowledge on practical and theoretical issues. Finding as an assumption becomes a making according to a directing alignment. Experimenting is a second well-known research practice that tests the boundaries of an established field of knowledge as well as a new concept, and reveals specific ways of knowing in the discipline. A third approach resides in catalysing in the sense of initiating and accelerating a reaction by providing a mediating step and leading it in a certain direction. It is linked to teaching practices and research formats as well as to exhibition concepts for uncovering different forms of knowledge, transmission, and communication.

With »Processes « as a further subtopic, specific features and grades of the reflexive stance begin to further crystallize (Buchert 2018). Architects, urban designers and landscape architects are trained to cope with complex questions and to shift between scales, tasks, tools, medias and actants, to act and reflect in multiple ways and to grasp uncertainty by imposing a kind of systematicity. A spectrum of tools, hybrid procedures and decision-making come into focus as well as driving forces in the context of questions such as 
how to start, stop and develop. These aspects outline a path to configure and understand research, and finally, a way of handling both the entanglement of design and research as well as transformations in different realms.

These are exemplary descriptions. The generation of further topics and inquiry remains viable, such as concerning values, relationality or projections. Moreover, the discussions at the symposia as well as within other academic discourse fields like, for example, the EU-funded project "Communities of tacit knowledge: Architecture and its ways of knowing (TACK 2019), provide possibilities to critically discuss and evaluate the reflexive and reflexivity, and test its intersubjective potential. Thus, such contextualization also contributes to a refining of the concept of »Reflexive Design«.

\section{Ongoing}

Reflexive approaches at their best entail a broad range of methodological engagement. For the development, articulation and communication of design knowledges, the notion of »Reflexive Design« emerged with a surprising power and with new realms of creative exploration. As a concept, it serves as a kind of binding and structuring alignment and trigger, capable of generating ideas and new directions. The peculiarity resides within the many different versions of combining research-oriented design approaches and design-oriented research that may co-exist. The knowledge it generates concerning designerly ways of knowing and acting as well as the formation and configuration of artefacts and further concepts - has the potential to be injected back into the realities it describes.

\section{References}

Beck, Ulrich/Giddens, Anthony/Lash, Scott (1996): Reflexive Modernisierung. Eine Kontroverse, Frankfurt am Main: Suhrkamp.

Bourdieu, Pierre/Wacquant, Loïc [1992]: Réponses: pour une anthropologie réflexive, Paris, Seuil. - English translation: An Invitation to Reflexive Sociology, Chicago: Chicago University Press, 1992.
Bourdieu, Pierre/Wacquant, Loïc (2001): Science de la science et réflexivité, Paris: Éditions Raisons d'agir - English translation: Science of Science and Reflexivity, Cambridge: Polity Press, 2004.

Bourdieu, Pierre [1980]: Le sens pratique, Paris: Les Éditions de Minuit. - English translation: The Sense of Practice, Athens: Alexandreia, 2006. 
Buchert, Margitta (2006): „Spielräume im Unbestimmten«, in: Margitta Buchert/Carl Zillich (eds.), Inklusiv. Architektur und Kunst, Berlin: Jovis, 54-59.

Buchert, Margitta (2011): »Formen der Relation. Entwerfen und Forschen«, in: Ute Frank et al. (eds.), EKLAT, Berlin: TU Universitätsverlag, 76-86.

Buchert, Margitta (2014): Reflexive Design. Design and Research in Architecture, Berlin: Jovis.

Buchert, Margitta (2016): Praktiken Reflexiven Entwerfens. Berlin: Jovis.

Buchert, Margitta (2018): Processes of Reflexive Design. Berlin: Jovis.

Buchert, Margitta (2021): »Design Knowledges on the Move«, in: Lara Schrijver (ed.), The Tacit Dimension. Architectural Knowledge and Scientific Research, Leuven: KU Leuven University Press, 83-96.

Cross, Nigel (1999): »Design research. A disciplined conversation«, in: Design Issues 15(2), 5-10.

Frayling, Christopher (1993): »Research in Art and Design«, in: Royal College of Art Research Papers 1(1993/94), London: Royal College of Art, 1-5.

Friedman, Ken (2003): »Theory Construction in Design Research. Criteria, Approaches and Methods «, in: Design Studies 24(6), 507-522.

Glanville, Ranulph (2010): »Reflection«, in: Adam Jakimovitz/Sarah Martens/Johan Verbeke (eds.) Reflections+13, Gent: ARC, 92-102.

Hoyningen-Huene, Paul (2013): Systematicity. The Nature of Science, Oxford: Oxford University Press.

Huber, Lara (2013): Der Philosoph und der Künstler. Merleau-Ponty als Denker der réflexion, Würzburg: Königshausen und Neumann.

Lawson, Bryan (2004): What Designers Know. Amsterdam et al.: Elsevier.
Lawson, Bryan (2006[1990]): How Designers Think. The Design Process Demystified, 4th edition, Amsterdam et al.: Elsevier Architectural Press.

May, Tim/Perry, Beth (2017): Reflexivity, London et al.: SACE.

Merleau-Ponty, Maurice [1942]: La Structure du comportement, Paris: Presses Universitaires de France. - English translation: The Structure of Behaviour, London: Beacon Press, 1963.

Merleau-Ponty, Maurice [1964]: Le Visible et l'invisible, Paris: Callimard. - Cerman translation: Das Sichtbare und das Unsichtbare, 2nd edition, Munich: Wilhelm Fink Verlag, 1994.

Merleau-Ponty, Maurice [1945]:

Phénoménologie de la perception. - English translation [1962]: Phenomenology of Perception, London: Routledge, 2012.

Merriam-Webster (2019): Dictionary. »Method", www.//merriam-webster.com/ dictionary/method, accessed June 22 , 2019.

Oechslin, Werner (2009): »Lost, but thus of even graver Concern: The Orientation of Architectural Theory to Practice«, in: Luise King/Stiftung Städelschule für Baukunst (eds.), Architecture \& Theory. Production and Reflection, Hamburg: Junius, 22-45.

Schön, Donald (2003[1983]): The Reflective Practitioner. How Professionals Think in Action, 3rd edition London: Ashgate.

Schön, Donald (1987): Educating the Reflective Practitioner, San Francisco: Jossey-Bass.

TACK (2019-2023): »ERC, Communities of Tacit Knowledge: Architecture and its Ways of Knowing«, Project no. 860413.

Wacquant, Loïc (1992): »Toward a Social Praxeology«, in: Pierre Bourdieu/Loïc Wacquant [1992]: Réponses: pour une anthropologie réflexive, Paris, Seuil. English translation: An Invitation to Reflexive Sociology, Chicago: Chicago University Press, 1992, 1-59. 
